\title{
Multiple Cultures, Multiple Literacies, and Collective Agencies: Chinese and Pakistani Immigrants' Perceptions of Family Literacy Support
}

\author{
Zheng Zhang (University of Western Ontario) \\ Nazia Bano (University of Western Ontario)
}

\begin{abstract}
Challenging the deficit view of immigrant families' roles in family literacy support, this study is situated in the multiliteracies theoretical framework, which celebrates marginalized, yet diverse, literacy practices in immigrant families. This study used semi-structured interviews and focus group discussions to map diverse family literacy practices in Chinese and Pakistani families. It explores whether and how available educational institutions have been inclusive of immigrant families' multiple cultures and multiple literacies. Adopting a bottom-up advocacy approach, this study also invites Chinese and Pakistani families to envision family literacy programs by themselves. It brings to light immigrant families' potential collective agencies in effecting changes to enable more inclusive family literacy programs in the culturally and linguistically diverse context of Canada.
\end{abstract}

\begin{abstract}
Résumé
Cet article défit la vision négative du rôle des familles d'immigrés dans le support de la littératie familiale. L'étude se situe dans le cadre conceptuel des multi-littératies qui supportent des pratiques de littératie marginalisées mais néanmoins très diverses dans des familles d'immigrés. La méthodologie d'entrevues semi structurées et de groupes de discussions utilisée a permis de décrire les différentes pratiques de littératie adoptées dans des familles chinoises et pakistanaises. Cette étude cherche également à explorer si les institutions éducatives ont pris en compte les différentes cultures et littératies des familles, et dans le cas positif, comment cette prise en compte s'est effectuée. L'analyse vise aussi à inviter les familles chinoises et pakistanaises à créer leurs propres programmes de littératie en utilisant une approche de soutien ascendant. Les résultats montrent un potentiel collectif d'agentivité qui pourrait engendrer la création de plus de programmes de littératie familiaux dans le contexte multiculturel et multilinguistique du Canada.
\end{abstract}

\section{CONTEXTS AND OBJECTIVES}

As the home to immigrants from more than 200 different ethno-cultural origins, Canada boasts of its distinct mosaic culture (Minister of Industry, 2008). As of 2006, South Asians (including East Indian and Pakistani) and Chinese immigrants are the largest and second largest visible minority groups in Ontario, respectively accounting for $28.9 \%$ and $21 \%$ of all visible minorities in the province. However, based on our initial research, settlement infrastructures like family literacy programs meeting immigrants' culture- and language-specific demands are more available in key gateway cities like Toronto and Vancouver where there is a much larger share of Canada's immigrant population and recent immigrant population than in the rest of the country (Citizenship and 
Immigration Canada, 2005). Family literacy organizations or services specifically supporting immigrant families are needed in smaller cities where there is a smaller but growing number of Canada's immigrants.

Studies show family literacy support not only facilitates learning in school but may actually enable it in some way (e.g., Purcell-Gates, 2000; Sample Gosse \& Phillips, 2006). Purcell-Gates, Jacobson, and Degener (2004) emphasized the role of family literacy support in raising children's phonemic awareness and concepts of print. Rowsell (2006) also contended that well-organized, longlasting family literacy initiatives that involve community partnerships can improve student achievement. Nevertheless, in Gregory's (2008) book, we see examples of immigrant families who have found it "a lonely and tough task" (p. $55)$ to educate their children at home. They have been looking for possible and appropriate ways of family support for their children's biliteracy development, especially those parents who are not confident with their capability to support home literacy in English as a second language.

Studies also reveal that the deficit notion of literacy development as regards immigrant families prevails in existing family literacy programs, which has thwarted inclusion of immigrant families into these mainstream programs in North-America (Hannon, 2003; Wang, 2008). Measured against the norms of Euro-American middle-class parenting (Stooke, 2005) and school-like literacy activities (e.g., story telling \& reading and writing), immigrant families from diverse backgrounds are regarded as having deficits in providing family literacy support (Hannon, 2003). Challenging the deficit view of immigrant families' roles in family literacy support, this study underscores culturally diverse modes of meaning making and celebrates marginalized literacy practices in immigrant families. By assuring immigrant parents of the positive roles of their diverse "funds of knowledge" (González, Moll, \& Amanti, 2005) in supporting their children's biliteracy development, this study documents Chinese and Pakistani families' diverse family literacy practices and explores whether and how educational institutions have been inclusive of immigrant families' multiple cultures and multiple literacies. Adopting a bottom-up advocacy approach, this study invites Chinese and Pakistani families to envision family literacy programs by themselves. It brings to light immigrant families' potential collective agencies in effecting change to enable more inclusive family literacy programs in the culturally and linguistically diverse context of Canada.

\section{LITERATURE REVIEW}

Sénéchal, LeFevre, Thomas, and Daley (1998) conducted research on the causal relationship between children's literacy development and two categories of 
interaction in home environment, i.e., informal storybook reading and formal parental instruction. Their findings reveal that informal message-focused home literacy activities explained statistically significant unique variance in children's oral-language skills but not in their written-language skills, while formal parent teaching about reading and writing explained statistically significant unique variance in children's written-language skills but not in their oral-language skills. In Sénéchal et al.'s series of research (Sénéchal et al., 1998; Sénéchal \& LeFevre, 2002), the causal relationship between home literacy experiences and children's literacy development is inferred from literacy experiences in middle- and upper middle-class families. Though Sénéchal et al.'s studies have contributed to the current knowledge about family literacy support, their findings about causality can hardly be applied to other family groups with different socioeconomic status (SES), language backgrounds, and sociocultural discourses. Considering the increasingly diverse population in Canada, variations in local family literacy activities are inevitable. Though there are abundant studies on empowering the diverse population of immigrant children and maintaining their first languages, most of the studies are limited to school practices and policy considerations within the school contexts (e.g., Cummins, Pray, \& Jimenez, 2009; Cummins, 2006; 2008). Those studies are emerging that value the multiple repertoires of family literacy practices and highlight the home-school-community collaborations for immigrant children's multiliteracies development (e.g., Cummins, Chow, Schecter, Yeager, B. \& et al., 2006; Gregory, 2008; Rowsell, 2006; Mehta, Khan, Rashkovsky, \& Schecter, 2006; Pahl \& Rowsell, 2005). Nevertheless, most of these studies are situated in key gateway cities in Canada or contexts other than Canada. Hence, research is needed that will focus on smaller cities where recent immigrants are flooding in while resources and services relevant to family literacy support are in scarcity. There is an urgent need for studies in such contexts to document the diverse variables of non-mainstream family literacy practices, map home -school links, or set up formal or informal family literacy programs that can empower immigrant parents and encourage their active participation in their children's multiliteracies education.

Based on her examination of texts on recommended parental activities, Stooke (2005) identified two major categories: the middle-class parenting model and the school-like literacy model. The first category is associated with EuroAmerican and middle-class parenting, while the other more closely resembles "activities routinely carried out in institutions such as schools and public libraries" (p. 7). Sample Gosse and Phillips (2006) noted that comprehensive family literacy programs targeting low-income families have been critiqued for measuring families' literacy practices against the norms of middle-class parenting 
and school-like literacy activities. Their child-focused components are more likely informed by the developmental theory "with its attendant assumptions of the naturally developing child and emergent literacy" (Comber, 2003, p. 355). Children are thus positioned as biological subjects who develop their literacy abilities with the right conditions and parental support. Instructors in these programs are assigned privileged roles as professionals who inform and train parents. To quote Stooke (2005), "there is a strong desire on the part of some professionals to guide and control parents' practices" (p. 7). Families might humbly give way to professionals because of an inferiority mentality toward their own literacy practices. Honoring efficiency as the value of education, programs underpinned by the developmental theories often label children who require more time and efforts for literacy achievement as deficits and problems. Parents who are measured against the norm of middle-class parenting and school-like literacy activities are also viewed as deficits (Hannon, 2003; Sample Gosse \& Phillips, 2006). Parents are conceived of as agents who lack appropriate knowledge or strategies to offer "formal" literacy support. In this sense, parents should be informed (of emergent literacy) and trained (in ways to help their children get ready to read) (Stooke, 2005) by means of various formal or informal family literacy programs. Studies on family literacy programs for marginalized families are emerging (e.g., Phillips, Hayden, \& Norris, 2006; Phillips \& Sample Gosse, 2005; Timmons, O’Donoghue, MacGillivray, \& Gerg, 2003). However, little is known about the existence and operation of family literacy support service programs specifically targeting immigrant families' diverse needs.

Against the "deficits" approach and focusing on middle-class and schoollike literacy, scholars urged due attention to capitalizing on diverse family literacy practices and strengthening home-school links (e.g., Gregory, 2008; Reyes \& Torres, 2007; Rodriguez-Brown \& Meehan; Rowsell, 2006; Sample Gosse \& Phillips, 2006; Wasik et al., 2001). Reyes and Torres (2007) employed a critical approach to family literacy programs, which is characteristic of "participatory, democratic, liberating, and dialogical" (p. 74). This approach opposes the stereotypes of middle-class and school-like literacy practices. It intends to create new venues to reposition, empower family and community members, and allow for collective transformative actions via relational pedagogy and collegial dialogue. Nevertheless, there is an urgent need for similar studies that support bottom-up advocacy and promote a more dialogical and inclusive curriculum of family literacy programs in smaller cities where there is a smaller share of Canada's immigrants, but which are witnessing an increasing number of recent immigrants from diverse cultural and linguistic backgrounds. 


\section{THEORETICAL FRAMEWORK}

Considering the increasing cultural and linguistic diversity in the globalized world, the New London Group (1996) has coined the term multiliteracies and called for a broader view of literacy in multicultural and multilingual contexts.

The New London Group (1996) differentiated "multiliteracies" from a more traditional notion - "mere literacy" (p. 64). Mere literacy is more focused on language, i.e., formalized, monolingual, monocultural, and rule-governed language forms. Mere literacy connotes traditional teaching and learning of reading and writing in "page-bound, official, standard forms of the national language" (p. 61). In contrast, the concept of "multiliteracies" highlights: 1) the focus on modes of representation instead of language alone, implying the multiplicity of the communication channels as related to the linguistic, the visual, the audio, the spatial, and the gestural (Kress, 2000; Barton \& Hamilton, 1998); 2 ) the focus on new forms of literacy that are responsive to rapid technological changes and the new global order (e.g., Cole \& Pullen, 2010; Kalantzis \& Cope, 2008; Lankshear \& Knobel, 2003); and 3) the focus on linguistic and cultural differences so as to increase local diversity and global connectedness (Cope \& Kalantzis, 2000; The New London Group, 1996). As is contrasted with "mere literacy", multiliteracies theories view previously non-official and non-standard modes of representations or literacies in peripheral communities as legitimated forms of literacy.

With regard to students developing bilingual literacies, Hornberger and Skilton-Sylvester (2000) challenged the biliteracy policies and practices in bi(multi)lingual settings which privilege one end of the biliteracy continua over the other. For example, multiple forms of oral and vernacular literacies are marginalized and ignored in contemporary biliteracy education contexts. Drawing on cases of biliteracy education in linguistically diverse settings, they also accentuated the privileged power of English literacy over students' L1s and the "assimilative 'charm' of English which pulled students' biliterate development towards English" (p. 101). Studies in Hornberger's (2003) edited volume on the continua of biliteracy reveal the necessity for literacy educators to value the repertoire of students' multiple literacy practices in school and local settings and enhance educators' comfort levels and knowledge of the standard and vernacular, the written and oral forms of students' L1 and L2 (e.g., Perez, Flores, \& Strecker, 2003). Martin-Jones and Jones (2000) insightfully argued that biliteracy contains a two-way distinction between codes. In contrast, terms pertaining to multiple literacies, like local literacies, indigenous literacies, and everyday literacies, refer to access to pluralistic codes which people "move in 
and out of with considerable fluency and subtlety as they speak and write" (p. 7). Street's $(1984,2003)$ differentiation of autonomous and ideological views of literacy, Hornberger and Skilton-Sylvester's seminal work, Hornberger's later volume on the continua of biliteracy, and Martin-Jones and Jones' collection of works, all urge an attention shift from literacy/biliteracy to multiliteracies.

A growing number of ethnographic studies on multiliteracies are geared to documenting periphery multiliteracies (i.e., non-official literacies). They primarily focus on bringing legitimate status to previously illegitimate literacies in immigrant families and strengthening home-school links in the school or home environment (e.g., Cummins, 2000; Pahl \& Rowsell, 2005). This multiliteracies framework has impacted our epistemological and methodological stands as researchers and inspired us to explore how periphery forms of literacy in immigrant families could be legitimated in the areas of family literacy supporting services and programs in Canada.

\section{COMING TO THE RESEARCH \& METHODS}

Bano did her M.Ed. study in Canada from 1998 to 2000 and came back to Canada to pursue her doctoral studies with her husband and her 6-year-old daughter in 2007. Zhang came to Canada from Mainland China in 2006, finished her M.Ed. study in 2008 in Canada, and continued onto her journey of doing the $\mathrm{PhD}$ study. Both of us have extensive experience of working with international students or immigrants with different languages and cultures in Canada. Now, as a mother of a 9-year-old and a cultural insider of Pakistani families, Bano thinks highly of what Pakistani parents can offer in terms of family literacy practices and pedagogies. Intending to be a cultural worker in the cross-border education arena, Zhang shares with Bano an epistemological position that people from different ethnic and linguistic backgrounds have different ways of seeing the world and different ways of meaning-making; each of the ways is worth attention and celebration. Together, we initiated this qualitative study by adopting a multiliteracies lens and a bottom-up approach to re-valuing immigrant families' diverse literacy practices and reconceptualizing comprehensive family literacy programs from the vantage points of immigrant families rather than a top-down approach emphasizing professionals' and educators' perspectives. Instead of a comparative study of Pakistani and Chinese immigrant families' perceptions of family literacy practices and programs, we combined our efforts to highlight the diversity and situatedness of family literacy issues against the multicultural and multilingual backdrop of Canada. Our journey started with explorations of the ways in which we could invite immigrant families to the knowledge production process. It intended to create initial spaces to enable immigrant families to 
envision a different world of family literacy supporting services and programs. It is an effort to celebrate immigrant families' inputs to family literacy pedagogies given their rich life experiences as linguistic and cultural brokers. Sharing Kincheloe's (n.d.) position as a scholar of education and multiculturalism, his words resonate well with us,

I have often observed how some of the most compelling insights I have encountered concerning pedagogy come from those individuals living and operating outside the boundaries of educational scholarship. Sometimes such individuals are not formal scholars at all but individuals who have suffered at the hands of educational institutions. Such experiences provided them a vantage point and set of experiences profoundly different than more privileged scholars. (p. 5)

The study asks these questions: 1) What family literacy practices are being carried out in Pakistani and Chinese families as reported by Pakistani and Chinese parents? 2) To what extent are current educational institutions (including schools and family literacy programs) helpful for Pakistani and Chinese immigrant parents with respect to family literacy support in both their L1s and English? 3) What are Pakistani and Chinese parents' visions of a comprehensive family literacy program especially targeting immigrant families?

This study is situated in a smaller city in Ontario, Canada, where there is small but growing number of recent immigrants to Canada. The study recruited 12 mainland Chinese and Pakistani immigrant families where both the parents and their young children are in the process of developing biliteracy, i.e., literacy in their first language (L1) and English. Only one parent from each Chinese family joined the interview, while the husbands and wives of three Pakistani families chose to participate in the interviews together. Table 1 shows participants' profiles. 


\begin{tabular}{|c|c|c|c|c|}
\hline Name & Major Home Languages & $\begin{array}{l}\text { Parents' } \\
\text { Years in } \\
\text { Canada }\end{array}$ & $\begin{array}{l}\text { Number of children } \\
\text { (Grade Levels) }\end{array}$ & Children's Years in Canada \\
\hline Yuan (Mom) & Mandarin & 7 Years & $1(\mathrm{SK})$ & Born in Canada \\
\hline Qing (Mom) & Mandarin & 2 Years & 1 (Grade 6$)$ & 2 Years \\
\hline Jing (Mom) & Mandarin & 9 Years & $\begin{array}{l}2 \text { (Grade } 3 \& \text { one } \\
\text { year old) }\end{array}$ & Both born in Canada \\
\hline Lang (Dad) & Mandarin & 4 Years & 1 (Grade 5) & 2 Years \\
\hline Huan (Mom) & Mandarin & 1 Year & 1 (Grade 3) & 1 Year \\
\hline Meng (Mom) & $\begin{array}{l}\text { Mandarin \& English to the } \\
1^{\text {st }} \text { born } \\
\text { English only to the } 2^{\text {nd }} \text { child }\end{array}$ & 7 Years & 2 (Grade $12 \&$ SK) & $\begin{array}{l}1^{\text {st }} \text { child: } 7 \text { Years } \\
2^{\text {nd }} \text { child Born in Canada }\end{array}$ \\
\hline Tanveer (Dad) & Urdu \& English & 2 Years & 1 (Grade 3) & 2 Years \\
\hline $\begin{array}{l}\text { Shehzad (Dad) } \\
\text { and Fatima } \\
(\text { Mom) }\end{array}$ & Urdu, Pashto, \& English & 4 Years & $\begin{array}{l}3 \text { (Grade } 5,3, \& 3 \\
\text { years old) }\end{array}$ & $\begin{array}{l}1^{\text {st }} \text { child: } 4 \text { Years } \\
2^{\text {nd }} \text { and third children born in } \\
\text { Canada }\end{array}$ \\
\hline Aliya (Mom) & Potowari \& English & 11 Years & $4($ Grade $8,4,3, \mathrm{JK})$ & $\begin{array}{l}1^{\text {st }} \text { child: } 11 \text { years } \\
\text { Other children born in } \\
\text { Canada }\end{array}$ \\
\hline $\begin{array}{l}\text { Amin (Dad) and } \\
\text { Nabila (Mom) }\end{array}$ & Urdu \& English & 2 Years & 2 (Grade 5 \& JK) & $\begin{array}{l}1^{\text {st }} \text { child: } 2 \text { Years } \\
2^{\text {nd }} \text { child born in Canada }\end{array}$ \\
\hline $\begin{array}{l}\text { Mukhtar (Dad) } \\
\text { and Samina } \\
\text { (Mom) }\end{array}$ & Urdu \& English & 4 Years & $2($ Grade $2 \& \mathrm{JK})$ & $\begin{array}{l}1^{\text {st }} \text { child: } 2 \text { Years } \\
2^{\text {nd }} \text { child: } 6 \text { months }\end{array}$ \\
\hline $\begin{array}{l}\text { Akber (Dad) and } \\
\text { Sofia (Mom) }\end{array}$ & Urdu & 4 Years & 3 (Grade $4,3,3)$ & 4 Years \\
\hline
\end{tabular}

Table 1. Profile of Participants.

We used the convenience method (Cohen, Manion, \& Morrison, 2007, p.113) to select participants. We began by approaching the participants we have known previously. After they granted permission to be interviewed, we asked them to inform other Chinese or Pakistani parents of this study. Those who were interested in participating contacted us directly.

We employed 60-minute semi-structured interviews to elicit Chinese and Pakistani immigrant parents' viewpoints on: 1) family literacy activities going on in their households; 2) their perceptions of sufficiency of the available support to immigrant families with respect to literacy; and 3) their perspectives regarding how comprehensive family literacy programs would specifically benefit immigrant parents and their children from diverse cultural and linguistic backgrounds. 
After the interviews, we conducted two focus group sessions separately for the two ethic groups. Each session lasted approximately 60 minutes. The focus group discussions were conducted in the participants' preferred language(s), i.e., Mandarin and Urdu. Different from the individual interview questions, focus group discussions intended to elicit parents' perspectives on: 1) the value of celebrating immigrant families' diverse language varieties, scripts, and multiple repertoires besides school-like literacy and English-related literacy; and 2) their perceptions of immigrant families' individual and collective agency in creating a comprehensive family literacy program specifically for immigrant families themselves.

\section{DISCUSSION AND CONCLUSIONS}

The Overarching Impact of English-Related School Literacy: Primary Discourses vs. Secondary Discourses

Sénéchal, LeFevre, Thomas, and Daley (1998) maintained that formal parental instruction shares strong features with school-like literacy practices. Both Chinese and Pakistani parents talked about how they would follow their cultural traditions of enforcing school-like literacy (i.e., reading and writing) in both L1 and second language (L2) in their spare time. In other words, formal forms of literacy are seen as a key part of family literacy practices in both Chinese and Pakistani families. All Chinese and Pakistani parents accentuated their efforts to maintain their children's L1s. While trying hard to keep their L1s at home, both Chinese and Pakistani families are aware of the key role of schooling in facilitating the maintenance of their L1s and cultures.

It is reported that the local Canadian schools are trying to include students' cultural and linguistic heritages in the formal schools. For example, most schools organized occasions like international community potlucks and concerts. Almost all the parents mentioned similar cultural events. Nevertheless, as Akber and Sofia commented, these activities, though intended to be inclusive of diverse immigrant cultures, were actually only scratching the surface of their cultures. In terms of cultural and linguistic heritages, their children seem to learn little from international community potlucks. As Akber and Sofia stated, in their eyes,an international food party is not held to boost children's learning or maintain their cultural heritage. For them, a food party is for parents because parents are the ones who prepared the exotic dishes and embedded the cultural components in food while their children just brought the food to school and had fun.

Most Pakistani and Chinese parents concurred that keeping L1s plays a determinant role in shaping their children's perceptions of who they are and what their cultural backgrounds are. Mukhtar and Samina said, “... when I take them 
back home I want them to know what their roots are and if they cannot communicate with them, it is going to be very difficult." Akber and Sofia noted, "If you are sacrificing your own language then they [you] will totally forgot yourself, yeah, your background." Nabila and Amin said, their kids are somewhat confused about who they are, Canadians or Pakistani. Instead of keeping their culturally specific customs and features, their children are wittingly or unwittingly socialized to a monoculture - the mainstream culture. For them, Canadian mainstream culture is not per se multicultural. Several Pakistani parents commented on the lack of inclusive programs for celebrating diversity and maintaining immigrants' L1s in the city where they live, unlike in gateway cities like Toronto where celebrating diversity was more common.

In a similar vein, some Pakistani parents shared that their children are losing both their L1 and cultural heritage and have adopted Canadian culture and language styles and "don't even know how to talk and how to speak respectfully in our language Urdu" ( Nabila \& Amin). It is not that Canadian ways are not polite. It is that Pakistanis have their culturally specific ways of courtesy. For example, calling teachers and elders by their first names is seen as a taboo in Pakistani culture. "We are afraid that our kids will not be Asian anymore"--such concerns are prevalent among Pakistani families. Gee's (2008) Discourse theory illuminates that Primary Discourses, i.e., families' ethnocultural backgrounds and early home socialization, play roles in shaping immigrant children's first social identities. Local, state, and national groups and institutions outside early home settings, like churches, gangs, schools, offices, constitute Secondary Discourses that are key parts of socialization processes. From the Pakistani respondents' perspectives, Secondary Discourses like schools exert overarching influences upon their children's identity formation. In some Pakistani parents' views, their efforts to maintain their heritage languages and values were often counterbalanced by the school curriculum and pedagogy which buttresses a mono-cultural and mono-lingual form of literacy--English-related school literacy. Contrasted with Pakistani parents' worries about their children's losing their L1, Chinese parents did not show the same concern. We posit that reasons for the difference might be related to the number of children, language(s) used at home, and the presence of grandparents. First of all, the more children, the harder for parents to reinforce the rule of "L1 only" at home. For all Chinese families, except Meng's, Mandarin is the primary home language, whereas all Pakistani families, except for Akber and Sofia's, use both L1s and English as home languages. Based on the interview data, children's years in Canada might or might not impact their L1 maintenance and identity formation. Yuan's son was born in Canada, but spoke very fluent Mandarin and was very well informed of 
Chinese traditions. It is worth noting that living with his grandparents, Yuan's son was always told, "Speak Mandarin please, otherwise grandparents would not understand you". Having been in Canada for one year, Lang's daughter kept practicing the traditional Chinese art--calligraphy and switched comfortably between English and Mandarin when she talked to Lang (bilingual) or her grandparents (Mandarin only) from Beijing.

Both Chinese and Pakistani parents depicted their children's resistance in learning L1s (e.g., Shehzad and Fatima's first born; Yuan's son when there is "too much" Mandarin writing practice after school). The overarching impact of the Secondary Discourse and the absence of home-school connection in terms of literacy practices were seen by parents as the major trigger of their children's resistance to their linguistic and cultural heritage. Both Chinese and Pakistani parents were well aware of limited resources and programs in the smaller city they live to help immigrant children maintain their L1s. Except for Sunday school at the Mosque where Arabic, Quran, and Namaz (Islamic prayers) were taught, there were few programs of similar kinds where they live. In these Sunday Schools, although the Pakistani people's religion is taught, L1s (e.g. Urdu, Hindi, etc) are not taught. Only the Arabic language or Islamic teaching in English is taught. Chinese parents talked about the role of local Chinese schools, though some were concerned about the educational "quality" and how much Mandarin their children could really learn there. Even for families where their children showed keen interest to learn their L1s (e.g., Tanveer's daughter, Aliya's daughter, Huan's daughter, and Akber and Sofia's children), parents believed literacy programs specifically targeting their cultures and languages would enhance their children's interest in L1s and facilitate their L1 and native culture maintenance.

\section{Multiple Forms of Family Literacy Practices \& Legitimate Periphery Multiliteracies}

Several family literacy practices were reported to have aided their children's learning, which reflect features of multiliteracies. Multiliteracies involves pluralistic communicative channels other than reading and writing (the New London Group, 1996), different language varieties and scripts, and complex and multiple repertoires that are carried over into different communicative events (Pahl \& Rowsell, 2005).

In the Chinese and Pakistani families, multiple forms of literacy practices and communication practices involved different languages, e.g., traditional book reading at home in both L1s and L2, writing in English, writing in Chinese and Urdu in some families. Reading practices are also associated with various genres of print literacy, e.g., reading storybooks and religious scripts. Reading the Quran 
is a big part of Pakistani family practices. Pakistani parents shared with us that Islamic teaching, via informal instruction, discussions, and informal storybook reading, plays a unique role in teaching their children to be a good person and to acquire intuitive conceptions of right and wrong. The Quran is written in Arabic; therefore, Pakistani families' Quran reading actually involves another language -Arabic. Reading the Quran in Arabic is more like a tradition for Pakistani people. Muslim children learn Quran even though they don't learn the meaning of the Arabic words. They just recite the Quran in Arabic. In other words, they don't really know what they are reading and what the Quran is telling them to do. Chinese parents Jing and Qing, who became Christians after coming to Canada, also tried to read The Bible in both Mandarin and English and say grace in Mandarin as an approach to maintaining their children's L1. Besides traditional print literacy, new literacies related with technology and multimodal literacies (Kress, 2000) involving different symbolic systems are also reported, i.e., visual and audio (e.g., cartoon books, TV and DVD, Pakistani Urdu Plays/Dramas, and classic and semi-classic songs; online audio story-telling in both Chinese and Urdu), and gestural and behavioral (e.g., playing various kinds of games, celebrations of various historical, traditional, and religious events). Story-telling on the Internet was frequently reported as a key family literacy practice in both Chinese and Pakistani families. Different from Chinese parents' traditional opposition to children's reading cartoon books, to arouse her kids' interest in Mandarin, Jing encouraged them to watch Chinese cartoon shows under parental surveillance. After her daughter came to Canada for one year, Huan has found online traditional folk stories a very useful tool to maintain her daughter's interest in the Chinese language and keep informed about Chinese culture and history. Listening to those folk stories has been a key part of their daily family schedule. Aliya made a very good use of family wedding movies. With three of them born and growing up in Canada, her kids were often impressed with Pakistani cuisine and dressing cultures demonstrated in the movies.

An increasing number of ethnographic studies on multiliteracies are emerging to document periphery multiliteracies (i.e., non-official literacies in non-mainstream communities). Adopting a broadened sense of literacy, scholars in the camp of multiliteracies focus on the richness of wisdom embedded in periphery literacies and intend to bring legitimate status to these previously illegitimate literacies (e.g., Cummins, 2000, 2001; Pahl \& Rowsell, 2005; Martin-Jones \& Jones, 2000). As is contrasted with "mere literacy", multiliteracies does not view previously non-official and non-standard modes of representations in the periphery communities as deficits, like those in Pakistani and Chinese families, but as legitimate forms of literacy that facilitate 
communication across borders. Parents reported, though local Canadian schools were encouraging students' use of L1s at home, they seldom tried to make homeschool links and fathom the depth of immigrant families' literacy practices. Given the reported absence of other educational institutions that might address immigrant families' specific literacy needs, all the Chinese and Pakistani parents were keen on the idea of setting up family literacy programs that are specifically tailored to include and celebrate multiple literacies and multiple cultures in immigrant families.

\section{Deconstruction of Professionalism vs. Plurality of Knowledge Construction}

Hannon (2003) observed that, generally, parents and caregivers might be easily humbled by educators' professional knowledge in school-like literacy practices. In this study, immigrant parents expressed their bewilderment at school-like literacy, literacy education in Canadian schools, and the Canadian education system. Most of the parents reported that because of cultural differences and the limited home-school connection, they knew little about what and how their children had learned at school. Limited Primary-Secondary Discourse interaction had also posed challenges to their family literacy support. Children did not have to be hardworking and competitive as they were back in their home countries because of different educational focuses in Canada. Some Pakistani and Chinese shared that Canadian education seems to be more focused on practical application of knowledge and on children's development as a person, while Chinese and Pakistani cultures pay more attention to scores and rankings. Unlike in their home countries, Pakistani and Chinese children seldom brought textbooks home after they came to Canada. Once their children encountered difficulties in their homework and needed parental support, parents often didn't know where to start and how to teach their kids. Some parents, like Jing and Tanveer, tried to use their Chinese or Pakistani ways to approach the problems; however, their children resisted saying this was not the way they were taught at school. Pakistani parent Mukhtar (a doctoral student in an Engineering program at the local university) shared, following his approach of teaching probability, his daughter failed to do well in a test. How he taught his daughter during her medical leave (i.e., the way Mukhtar was taught in Pakistan) was totally different from what was expected from the school test here in Canada. Pakistani parents Nabila and Amin said, though in their eyes, memorization is a useful tool for learning (e.g., multiplication tables), unfortunately, their children are not using it extensively as they did before because now they are more used to the Canadian ways of practical and experiential learning.

Some parents anticipated more chances for them to talk to schools and for 
schools to be more transparent to immigrant parents and inform parents more often of the school practices. Families do want to learn more about the ways that can better engage their children in their L1 and L2 literacy learning. This finding corroborates Phillips and Sample Gosse's (2005, cited in Sample Gosse \& Phillips, 2006) findings that parents are aware of their "deficits" and they are most willing to learn school ways of literacy support. Hannon (2003) argued there is nothing wrong with parents acknowledging that there are family support strategies they do not know and they want to know, because awareness of the socalled "deficits" helps parents engage in conscious learning in family literacy programs. In this sense, it is not acknowledging parents' knowledge gaps in literacy support that is blamable, but the mindset that deficits are all immigrant families have (Hannon, 2003, p. 105).

Some parents felt intimidated when talking to Canadian teachers. Van Galen (2004) challenged that it is the professionals' assumption of the superiority of their intellectual interpretations of the world that obscures the capacity of those who might have represented their worlds with more visibly rough edges. However, we would argue, it is not the North American professionals that are to blame. The privileged image of educational professionals is well-established even in the Chinese and Pakistani participants' home countries. Several parents, such as Jing, Akber, and Sofia, talked about how teachers in their home countries were seen as authorities and how they were revered by parents. Their reliance on and respect for educational professionalism extended beyond the walls of formal schooling. Almost all Chinese and Pakistani parents talked about paying tuition fees to out-of-school tutoring for their kids for weekday nights, weekends, and holidays back in Pakistan and Mainland China. What we have found in the study is that for parents who felt too intimidated to approach professionals at school, some of them were worried about their communication skills in English. Some were concerned about whether their ways of approaching Canadian teachers might be aggressive or might not be culturally appropriate. Basic communicative skills and culturally appropriate ways to interact with Canadian teachers were reported to be two key things parents would love to be informed of in future family literacy programs.

In this study, we made it explicit to the immigrant parents that we were inviting them to contribute ideas as a bottom-up reconceptualization of family literacy programs. At first, we feared our presence as doctoral students in education might also be intimidating to them. However, once the idea of bottomup advocacy got across to the parents, individual parents' abundant resources and ideas about literacy and biliteracy development came through. As Edwards, Pleasants, and Franklin (1999) contended, "if teachers were to allow able parents 
to act like skilled novelists, parents would create stories, and it is through these stories that parents would be able to incorporate even seemingly unconnected bits and pieces about their children into a cohesive literacy life story" (p. xxiii). Parents' narratives included informative examples of biliteracy development, e.g., those about L1 loss and maintenance, confusions in early years of biliteracy development, and even stories about BICS (Basic Interpersonal Communication Skills) and CALP (Cognitive Academic Language Proficiency) (Cummins, 2000). Some Chinese parents reported how learning two languages helped enhance their children's phonetic awareness and thus helped them learn other languages like Spanish and French. Chinese parents reported how maintaining their children's L1 has helped their children's cognitive development and academic achievement, especially in the field of mathematics. Some parents' reports about how certain features of Mandarin have helped their kids' achievement in math are quite similar to Malcolm Gladwell's (2008) observation in his Outliers- The Story of Success. Parents of both communities talked about how language and math intersect, for example how the Chinese multiplication table could speed up their kid's calculation in math.

Deconstruction of Skepticism \& Construction of Collective Agency

The "Family literacy program" seems to be a contested term. Purcell-Gates (2000) referred to three types of family literacy programs, i.e., 1) programs that only feature adult education, 2) programs that only feature early childhood programming, and 3) programs with instruction delivered directly to both adults and children. What we were addressing in the interviews and focus groups is comprehensive family literacy programs that incorporate childhood programming (not limited to early childhood programming) and adult education along with an element of parents and children working together (Wasik, Dobbins, \& Herrmann, 2001). The assumption underlying comprehensive family literacy programs is that skills learned and practiced by the adults and the children produce an "intergenerational and/or reciprocal transfer of skills" (Neuman, 1998, cited in Sample Gosse \& Phillips, 2006, p. 122). The beneficiaries of such programs vary depending on the relative emphasis on adult-focused or child-focused components. Child-focused components would be helpful to advance children's literacy abilities, such as developmentally appropriate scaffolding strategies to promote literacy learning and strategies that "encourage a positive attitude towards learning" (Phillips, Hayden, \& Norris, 2006). Parent-focused components would advance adult literacy development, focusing on individualized goals pertinent to "parent-child learning or to employment"(Brizius \& Foster, 1993, cited in Sample Gosse \& Phillips, 2006, p. 122). The child-focused components could be controversial depending on how 
literacy development is perceived, e.g., in terms of the traditional developmental theories, sociocultural theories, or theories with transformative orientations. Moreover, engaging families in children's literacy development is also a complex process that involves evaluation of parental activities and abilities, i.e., what families have already known and what they need to and want to know about literacy support. As Hannon (2003) cautioned, the process of using and valuing what families already know in order to teach them what they do not know is subtle and can easily go wrong.

During the individual interviews, most of the parents liked the idea of setting up a comprehensive family literacy program for diverse immigrant families with themselves joining the process of curriculum development and operation. However, some parents did express their concerns about 1) lack of time; 2) uncertainty of parents' willingness to be the "risk-takers"; 3) language barriers (especially English proficiency levels and accents); and 4) conflicts that might result from religious and cultural differences.

Vincent (2000) identified participative strategies that can increase parents' participation in collective action. Concurring with her theory, in this study, for participative strategies that are rooted in immigrant parents' immediate experience and realities, they allowed parents to be assured that collective action is a useful strategy. Before the focus group discussion started, we highlighted that as minority groups in the multicultural and multilingual society, researchers' or educators' construction of communities for non-mainstream immigrant parents is not sufficient. We need a construction of communities by non-mainstream families themselves to advocate for collective voices and actions. During the focus groups, Chinese and Pakistani parents talked about Canadian people's less active acceptance of immigrants' cultures and accents and Canadian schools' "superficial" inclusion of multicultural components in the school system. Later on, they questioned their own passive roles in creating opportunities to make a difference and challenged their own stereotypical conceptions of the Canadians. Contrasted with their overall concerns with their children's L1 loss and their "inability" to support their children's literacy development in English in the individual interviews, in the focus discussions, they started to see hopes in their own agency and strengths. They also expressed their strong willingness to participate in future programs as "pioneers". In the focus groups, when specifically asked about what challenges we would face in such bottom-up family literacy programs, some of the parents mentioned that there might be a lot of challenges popping up in the process of implementing the programs, but they were confident that no difficulty is undefeatable. They believed that persistent actions can make differences. To quote the Chinese parent Meng, "Eventually, we 
might not achieve our original goals. But the bits and pieces we have done will definitely make some differences".

The focus groups did help energize parents' initiatives to create space to better employ their own resources, wisdom, and agency to make a difference in the current landscape of family literacy programs. Parents were excited about their pioneer roles in the future family literacy programs. They also showed enhanced awareness of their agency in helping and empowering each other. To quote Fatima,

We need a platform where we can discuss these issues and which provides all required services. Where we can support each other as well; suppose if you have a good working position while I am a needy person and you know available job opportunities so you can tell me about that. There should be a platform where Pakistani can go.

When talking about their strengths that they can bring to the future comprehensive family programs as "experts", parents were sort of "shy" in the individual interviews. During the focus group discussions, when we talked about releasing their individual and collective agency, they became very excited, suggested several ways, and envisioned several beginning steps that future comprehensive family literacy programs could take: 1) to enhance parents' interactions with parents from diverse cultural backgrounds, 2) to share information regarding family literacy support, and 3) to organize culture-related literacy events to engage their children in learning and maintaining their L1s in a community-based learning environment. Jing and Qing were Mandarin teachers back in China. They expressed strong confidence in teaching Mandarin and Chinese culture to people of various age groups and ethnocultural backgrounds. Lang is good at Chinese calligraphy and felt excited about teaching this traditional Chinese art to diverse people in Canada. When asked about Pakistani cuisine culture and Pakistani needlework, Aliya was quite confident about what she could contribute, "I can make everything". Most importantly, immigrant parents have always been the experts fighting in the frontier of their children's biliteracy development, which has been previously invisible to professionals.

To sum up, when asked about literacy practices they wish to see in family literacy programs, both Chinese and Pakistani families envision family literacy programs targeting diverse immigrant families to play various roles: 1) meeting children's and parents' culturally-specific needs in literacy learning and development; 2) permeating home-school boundaries and facilitating homeschool interactions; 3) bringing in professional knowledge about literacy learning, encouraging immigrant families' input, and respecting their insights as reciprocal resources; 4) facilitating exchanges of resources among families from 
diverse backgrounds; and 5) organizing culture-related literacy events to engage their children in learning and maintaining their L1s in a community-based learning environment.

\section{SIGNIFICANCE OF THE STUDY}

Adopting a critical lens, Reyes and Torres (2007) used "colonizing mentality" (p.

75) to define the assumption underlying the current family literacy programs targeting non-mainstream families. They contended that these non-mainstream families have been "colonized" and regarded as deficits because they are measured against the norm of Euro-American and middle-class family literacy practices. Such family literacy programs are assumed to take the role of " 'fixing' the non-mainstream families, instead of collaboratively identifying and solving the problems that alienate both the families and their children and obstruct their progress toward full literacy" (p. 75).

Considering the regional imbalance of immigrant distribution in Ontario, Canada (Akbari \& Harrington, 2007), regional immigration and settlement strategies are in urgent need. With regard to insufficient bilingual family literacy support for diverse immigrant families in smaller cities in Ontario, this study will provide insights into initiatives that intend to challenge the deficits views of immigrant parents' literacy support abilities. The findings regarding immigrant parents' perceptions and suggestions for future orientations of family literacy programs will be helpful for program/curriculum development of current and future family literacy programs. The study will also illuminate future initiatives that support bottom-up advocacy. It will also offer suggestions to schools, educational institutions, and current mainstream family literacy programs to value and celebrate the plurality of immigrant family literacy practices. The researchers are considering a future action research study that focuses on possibilities to incorporate immigrant families' agency and expertise, rooted in their immediate experiences and realities. Comprehensive family literacy programs specifically involving immigrant families' agencies will not only foster awareness of co-ordination and community involvement, but also increase immigrant families' consciousness of their own agency and expertise. All these might be key contributors to successful settlement programs in smaller cities or towns in Ontario. Moreover, such comprehensive programs could incorporate childhood programming and adult education for English Language Learners (ELLs) with an element of parents and children working together (Wasik et al., 2001). Such programs might serve as a pivotal strategy to improve the literacy (or biliteracy) levels of all Canadians. Involving parents and educational practitioners from diverse cultural backgrounds, comprehensive family literacy 
programs intend to establish a platform for culturally and linguistically diverse parents and educational practitioners to interact with each other and build a better understanding among all Canadians.

\section{References}

Akbari, A. H. \& Harrington, J. S. (2007). Initial Location Choice of New Immigrants to Canada. Atlantic Metropolis Centre Working Paper Series, No. 05. Retrieved July 22, 2009, from http://www.atlantic.metropolis.net/index_e.html

Barton, D., \& Hamilton, M. (1998). Local literacies: Reading and writing in one community. London, UK: Routledge.

Citizenship and Immigration Canada. (2005). Recent immigrants in metropolitan areas: Canada - A comparative profile based on the 2001 Census. Ottawa: Public Works and Government Service Canada.

Cohen, L., Manion, L., \& Morrison, K. (2007). Research methods in education. London, UK: Routledge.

Cole, D. R., \& Pullen, D. L. (Eds.) (2010). Multiliteracies in motion: Current theory and practice. New York, NY: Routledge.

Comber, B. (2003). Critical literacy: What does it look like in the early years? In N. Hall, J. Larson, \& J. Marsh (Eds.), Handbook of early childhood literacy (pp. 355-368). London, UK: SAGE Publications.

Cope, B., \& Kalantzis, M. (2000). Introduction: Multiliteracies: The beginnings of an idea. In B. Cope \& M. Kalantzis (Eds.), Multiliteracies: Literacy learning and the design of social futures (pp. 3-8). London, UK: Routledge.

Cummins, J. (2000). Language, power and pedagogy: Bilingual children in the crossfire. Toronto, Ontario, Canada: Multilingual Matters Ltd.

Cummins, J. (2001). Bilingual Children's Mother Tongue: Why Is It Important for Education? Sprogforum, $7(19), 15-20$.

Cummins, J. (2006). Multiliteracies and equity: How do Canadian schools measure up? Education Canada, 46(2), 4-8.

Cummins, J. (2008). Where immigrant students succeed: A comparative review of performance and engagement in PISA 2003. Curriculum Inquiry, 38(4), 493-497.

Cummins, J., Chow, P., Schecter, S. R., \& Yeager, B. et al. (2006). Community as curriculum. Language Arts, 83(4), 297-307.

Cummins, J., Pray, L., \& Jimenez, R.T. (2009). Literacy and English-language learners: A shifting landscape for students, teachers, researchers, and policy makers/A response to literacy and English-language learners: A shifting landscape for students, teachers, researchers, and policy makers. Educational Researcher, 38(5), 382-385.

Edwards, P. A., Pleasants, H. M., \& Franklin, S. H. (1999). A path to follow: Learning to listen to parents. Portsmouth, NH: Heinemann.

Gee, P. (2008). Social linguistics and literacies: Ideology in discourses. London, UK: Routledge

Gladwell, M. (2008). Outliers-the story of success. London, UK: Little, Brown and Company.

González, N., Moll, L. C., \& Amanti, C. (2005). Funds of knowledge: Theorizing practices in households, communities, and classrooms. Lawrence: Erlbaum Associates.

Gregory, E. (2008). Learning to read in a new language: Making sense of words and worlds (2nd ed.). Los Angeles, CA: SAGE.

Hannon, P. (2003). Family literacy programmes. In N. Hall, J. Larson, \& J. Marsh (Eds.), Handbook of early childhood literacy (pp. 99-111). London, UK: SAGE Publications.

Kalantzis, M., \& Cope, B. (2008). Language education and multiliteracies. In T. May \& N. H. Hornberger (Vol. Ed.), Encyclopedia of language and education: Vol. 1. Language policy and political issues in education (pp. 195-212). New York, NY: Springer.

Kincheloe, J. L. (n.d.). The power of difference in knowledge production: Multilogicality in the bricolage and $\begin{array}{lllll}\text { Postformalism. } & \text { Retrieved } & \text { September } & 9, & \text { from }\end{array}$ http://freireproject.org/articles/node\%2065/Research/ThePowerofDifferenceinKnowledgeProduction.doc

Kress, G. (2000). Multimodality. In B. Cope \& M. Kalantzis (Eds.), Multiliteracies: Literacy learning and the design of social futures (pp. 182-203). London, UK: Routledge.

Lankshear, C., \& Knobel, M. (2003). New literacies: Changing knowledge and classroom practice. 
Buckingham, UK: Open University Press.

Martin-Jones, M., \& Jones, K. (2000). Multilingual literacies: Reading and writing different worlds. Philadelphia, PA: John Benjamins.

Mehta, P., Khan, Z., Rashkovsky, K., Schecter, R. (2006). Diversity as a resource at Floradale Public School. Paper represented at CSSE, Toronto, Ontario, Canada: York University.

Minister of Industry (2008). Canada's ethnocultural mosaic, 2006 census. Retrieved July 20, 2010, from http://www12.statcan.ca/english/census06/analysis/ethnicorigin/pdf/97-562-XIE2006001.pdf

Pahl, K., \& Rowsell, J. (2005). Literacy and education: Understanding the new literacy studies in the classroom. London, UK: Paul Chapman Publishers.

Phillips, L., Hayden, R., \& Norris, S. P. (2006). Family literacy matters: A longitudinal parent-child literacy intervention study. Calgary, Alberta, Canada: Detselig Enterprises.

Phillips, L. M., \& Sample Gosse, H. L. (2005). Family literacy: Listen to what the families have to say. In J. Anderson, M. Kendrick, T. Rogers, \& S. Smythe (Eds.), critical issues in family, community, and school literacies: Intersections and tensions (pp. 91-107). Mahwah, NJ: Lawrence Erlbaum Associates.

Purcell-Gates, V. (2000). Family literacy. In M. L. Kamil, P. B. Mosenthal, P. D. Pearson, \& R. Barr (Eds.), Handbook of reading research (Vol. III, pp. 853-870). Mahwah, NJ: Lawrence Erlbaum Associates.

Purcell-Gates, V., Jacobson, E., \& Degener, S. (2004). Print literacy development: Uniting cognitive and social practice theories. London, UK: Harvard University Press.

Reyes, L. V., \& Torres, M. N. (2007). Decolonizing family literacy in a culture circle: Reinventing the family literacy educator's role. Journal of Early Childhood Literacy, 7(1), 73-94.

Rodriguez-Brown, F. V., \& Meehan, M. A. (1998). Family literacy and adult education: Project FLAME. In M. C. Smith (Ed.), Literacy for the twenty-first century: Research, policy, practices, and the national adult literacy survey (pp. 175-193). Westport, CT: Praeger.

Rowsell, J. (2006). Family literacy experiences: Creating reading and writing opportunities that support classroom learning. Markham, Ontario, Canada: Pembroke Publishers.

Sample Gosse, H., \& Phillips, L. (2006). Family literacy in Canada: Foundations to a literate society. In A. McKeough, L. M. Phillips, V. Timmons, \& J. L. Lupart (Eds.), Understanding literacy development: A global view (pp. 113-135). Mahwah, NJ: Lawrence Erlbaum.

Sénéchal, M., \& LeFevre, J. (2002). Parental involvement in the development of children's reading skills: A five-year longitudinal study. Child Development, 73(2), 445-460.

Sénéchal, M., LeFevre, J., Thomas, E., \& Daley, K. (1998). Differential effects of home literacy experiences on the development of oral and written language. Reading Research Quarterly, 33(1), 96-116.

Stooke, R. (2005). 'Many hands make light work' but 'too many cooks spoil the broth': Representing literacy teaching as a 'job for experts' undermines efforts to involve parents. Journal of Curriculum Studies, 37(1), 3-10.

The New London Group. (1996). A pedagogy of multiliteracies: Designing social futures. Harvard Educational Review, 66(1), 60-92.

Timmons, V., O’Donoghue, F., MacGillivray, T., \& Gerg, B. (2003). A comprehensive family literacy program in rural Atlantic Canada. Paper resented at the second annual scientific conference of the Canadian Language and Literacy Research Network, Victoria, BC.

Van Galen, J. A. (2004). Seeing classes: Toward a broadened research agenda for critical qualitative researchers. International Journal of Qualitative Studies in Education, 17, 663-684.

Vincent, C. (2000). Including parents?: Education, citizenship, and parental agency. Philadelphia, PA: Open University.

Wang, L. (2008). Immigration, literacy, and integration: An ethnography of recent Chinese immigrants' literacy practices in their integration trajectories in Ontario: A summary report. Retrieved May 24, 2010, from http://ceris.metropolis.net/research-policy/GradStudentAwardReports/Wang2008.pdf

Wasik, B.H., Dobbins, D.R., \& Herrmann, S. (2001). Intergenerational family literacy: Concepts, research, and practice. In S.B. Neuman, \& D.K. Dickinson (Eds.), Handbook of early literacy research (pp. 444-458). New York, NY: Guilford Press.

Zheng Zhang (zzhan8@uwo.ca) is a PhD candidate at the University of Western Ontario. Her research interests include English academic writing, multiple literacies and literacy curriculum.

Nazia Bano (nbano@uwo.ca) is a PhD student at UWO. Her research interests include indigenous education, critical perspectives of development, alternative models of education, and critical pedagogy. 